\title{
PRESENCE OF INTRAMYOCARDIAL FAT TISSUE IN THE RIGHT ATRIUM AND RIGHT VENTRICLE - POSTMORTEM HUMAN ANALYSIS
}

\author{
Kristina Selthofer-Relatić1,2, Tatjana Belovari ${ }^{3}$, Nikola Bijelić ${ }^{3}$, \\ Aleksandar Kibel ${ }^{1,4}$ and Jasmina Rajc ${ }^{5}$ \\ ${ }^{1}$ Department of Cardiovascular Disease, Osijek University Hospital Centre, Osijek, Croatia; \\ ${ }^{2}$ Department of Internal Medicine, Faculty of Medicine, Josip Juraj Strossmayer University of Osijek, \\ Osijek, Croatia; ${ }^{3}$ Department of Histology and Embryology, Faculty of Medicine, Josip Juraj Strossmayer \\ University of Osijek, Osijek, Croatia; ${ }^{4}$ Department of Physiology and Immunology, Faculty of Medicine, \\ Josip Juraj Strossmayer University of Osijek, Osijek, Croatia; ${ }^{5}$ Department of Pathology and Forensic Medicine, \\ Osijek University Hospital Centre, Osijek, Croatia
}

\begin{abstract}
SUMMARY - Histologic and radiologic studies describe intramyocardial fat tissue as a normal finding or as part of cardiac pathology. The role of fat cells within the myocardium is not fully understood. The aim of this study was to assess fat tissue distribution in the myocardium of right atrium (RA) and right ventricle (RV) and age differences in subjects free from cardiac disease. The study included 10 males without cardiac disease divided into two groups according to age (below/above 50 years). Three cross sections were performed (RV free wall and apex and RA free wall) with histomorphological analysis on digital photographs. The shares of total myocardial fat (TMF), perivascular fat (PVF) and non-perivascular (nPVF) fat were calculated. Samples from the older group had larger amounts of fat in the epicardium and myocardium, without statistically significant difference (TMF $\mathrm{p}=0.847, \mathrm{PVF} p=0.4$ and $\mathrm{nPVF} \mathrm{p}=0.4)$. The largest quantities of fat tissue were found in the RV apex samples (14.9\%), followed by RV free wall (7.5\%) and RA (4.5\%), where total apical RV fat share was significantly larger than in RA sample $(\mathrm{p}=0.044)$. Intramyocardial fat cells were present within the non-diseased RA and RV in all samples, mostly in the apex. Further investigations on age difference, effect of visceral obesity and sex differences are needed.
\end{abstract}

Key words: Myocardium - pathology; Pericardium - pathology; Heart atria; Heart ventricles; Heart diseases; Adipose tissue - pathology; Body fat distribution - epidemiology

\section{Introduction}

In addition to normal adipose tissue that surrounds the heart and the great blood vessels (epicardial and pericardial adipose tissue, paracardial or mediastinal adipose tissue and pericoronary or perivascular epicar-

Correspondence to: Asst. Prof. Kristina Selthofer-Relatic, $M D, P h D$, Department of Cardiovascular Disease, Department of Internal Medicine, School of Medicine, Josip Juraj Strossmayer University of Osijek, J. Huttlera 4, HR-31000 Osijek, Croatia

E-mail: selthofer.relatic@gmail.com

Received April 13, 2017, accepted December 6, 2017 dial fat), fat is also stored within the cardiomyocytes, mostly in the form of triglyceride droplets ${ }^{1,2}$. This myocardial fat constitutes less than $1 \%$ of the total organ mass ${ }^{1}$. Myocardial triglyceride stores are known to be increased in certain conditions, such as obesity, impaired glucose tolerance, and type 2 diabetes ${ }^{2}$. However, observations also indicate that damaged myocardium, such as in myocardial infarction, can be infiltrated by adipose cells, which is often identified under the term lipomatous metaplasia ${ }^{3}$. Lipomatous metaplasia is a remodeling process characterized by replace- 
ment of collagen by interstitial adipocytes and continues for several months to years after myocardial infarction ${ }^{4}$. Fatty infiltration of the myocardium can be present in isolation or in association with fibrous tissue ${ }^{5,6}$. It has been observed in histologic studies of samples from endocardial biopsies and autopsies, as well as in radiological imaging studies ${ }^{5}$. Although it is correlated with various cardiomyopathies, it also exists to a certain degree in normal myocardium ${ }^{5,7}$. The physiological and pathophysiological roles of these clusters of fat cells or individual fat cells within the myocardium are not fully understood ${ }^{5,7}$.

Physiologically, intramyocardial fat tissue is predominantly located in the right ventricle, while only a small amount is found in the left ventricular wall, in its apical $\operatorname{part}^{7}$. Adipose tissue infiltration in the right ventricle starts in the epicardium and expands gradually to the endocardium, depending on the level of infiltration. In cases of slight fatty infiltration, it is typically located in perivascular connective tissue, whereas a larger amount of intramyocardial fat is present in persons with increased amount of epicardial adipose tissue. Fat cells within the myocardium are usually interspersed among myocardial fibers without cardiomyocyte replacement, fibrosis, or signs of inflammation $^{7}$. Intramyocardial fat as a pathophysiological finding, in addition to the previously mentioned myocardial infarction, is connected to other conditions including arrhythmogenic right ventricular dysplasia, lipomatous hypertrophy of the interatrial septum, dilative cardiomyopathy, cardiac lipoma, tuberous sclerosis complex, and muscular dystrophies ${ }^{7}$. While cardiac fat and intramyocardial triglyceride accumulation might be connected with the pathophysiology of arrhythmias (and sudden cardiac death), potentially interfering with the conduction system of the heart, there is insufficient knowledge about its exact role and its possible involvement in the pathogenesis of left ventricular dysfunction ${ }^{1,2,4}$.

The aim of this study was to assess fat cell and fat tissue occurrence in the right atrium and right ventricle of subjects who did not have evident heart disease. Furthermore, we aimed to determine if there was any apparent difference in intramyocardial fat tissue presence in the right heart between young and old adults, which could give us some important clues about the physiological roles of intramyocardial fat and its changes during aging.

\section{Materials and Methods}

The study was conducted at the Department of $\mathrm{Pa}$ thology and Forensic Medicine, Osijek University Hospital Centre, upon approval from the institutional Ethics Committee. The study included 10 males divided into two groups according to age. The first group consisted of males less than 50 years of age and the second group comprised males older than 50 years. The inclusion criteria were male gender, no known cardiac disease, or any specific findings on autopsy. Both groups of patients died from non-cardiac causes (accidental deaths in the younger group). During autopsy, three cross sections of the right heart were performed. The

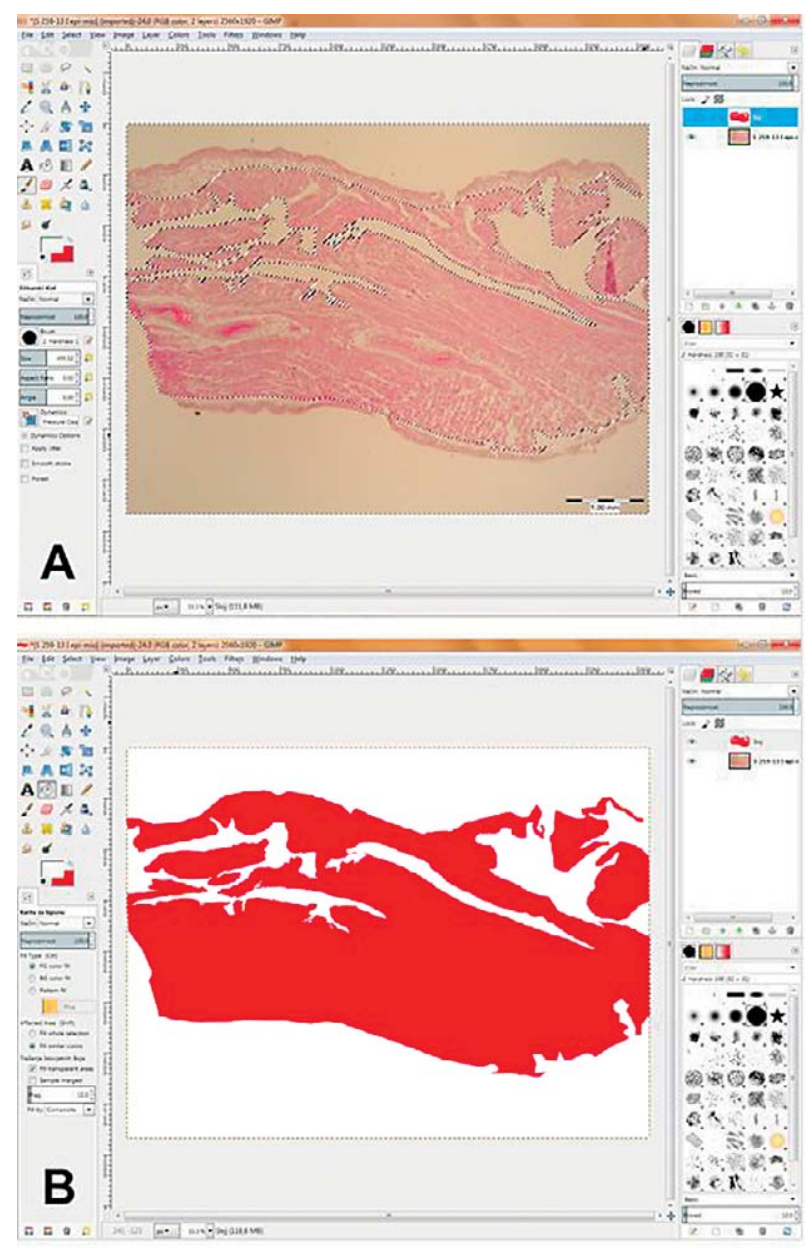

Fig. 1. (A) Digital photograph of a histologic section of $R A$ open in the open-source imaging software GIMP during the tissue selection process. Only the myocardial layer is selected, and larger artifacts are being subtracted from the selection; (B) a color 'mask' is applied in GIMP order to prepare the image for measurement in FIJI. 

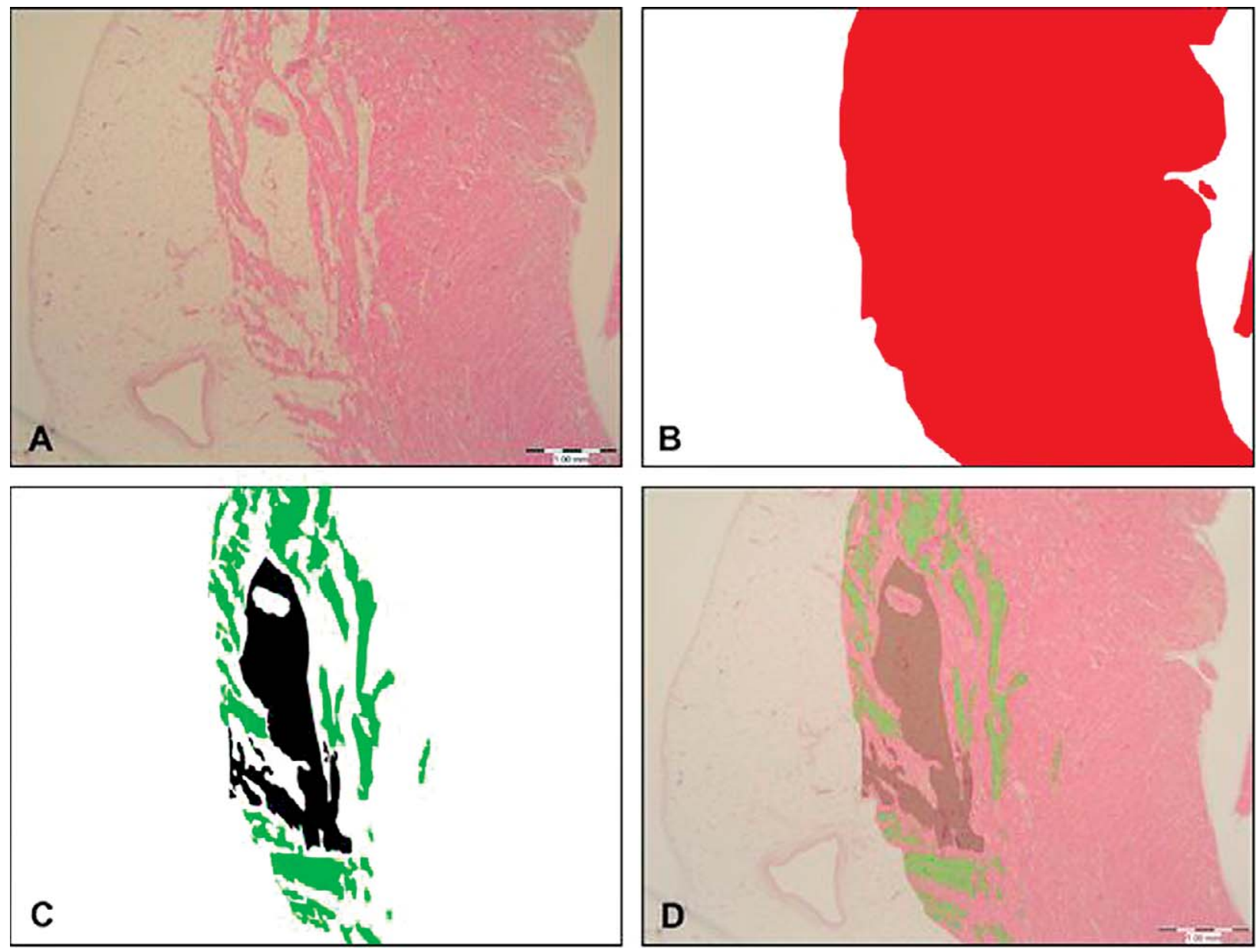

Fig. 2. Preparation of images for measurement: $(A)$ digital photograph of a section of $R V$ stained with hematoxylin and eosin. Scale bar: $1 \mathrm{~mm}$; (B) the same image after application of a color mask over the myocardial layer (red), while other tissues and empty space were filled with white color; $(C)$ the same image after selecting the fat tissue and application of color masks over perivascular fat tissue area (black) and non-perivascular fat tissue area (green). Everything else was filled with white color; (D) a control image with partially transparent masks where the selection can be checked for major inconsistencies and masks can be adjusted accordingly.

first two samples were obtained from the right ventricular (RV) and right atrial (RA) free lateral wall, and the third sample was obtained from the RV apex. All 30 specimens were prepared in similar fashion: after fixation in $10 \%$ buffered formalin overnight, they were processed and embedded in paraffin wax, cut at $4 \mu \mathrm{m}$, and stained with hematoxylin and eosin. Slides were photographed using an Olympus C-5050 camera on Olympus BX-50 light microscope (Olympus, Tokyo, Japan) and QuickPHOTO Pro imaging software (Promicra s.r.o., Prague, Czech Republic).

Thickness of the thickest and thinnest visible parts of the epicardium was measured using FIJI, a distribu- tion of Image J software ${ }^{8,9}$. Mean epicardium thickness was calculated and used on statistical analysis. Digital photographs of the myocardium were taken in a way to encompass the largest visible fat deposits on the slide. Digital photographs were processed in opensource and free imaging software GIMP (GNU Image Manipulation Program, The GIMP team, GIMP 2.8.10, www.gimp.org) in order to create colored 'masks' of certain tissue areas (red for myocardial layer, black for perivascular fat tissue, and green for nonperivascular fat tissue) (Figs. 1 and 2). Digitally created mask images were then opened in FIJI, converted to 8-bit images and areas of myocardial layer and fat tis- 


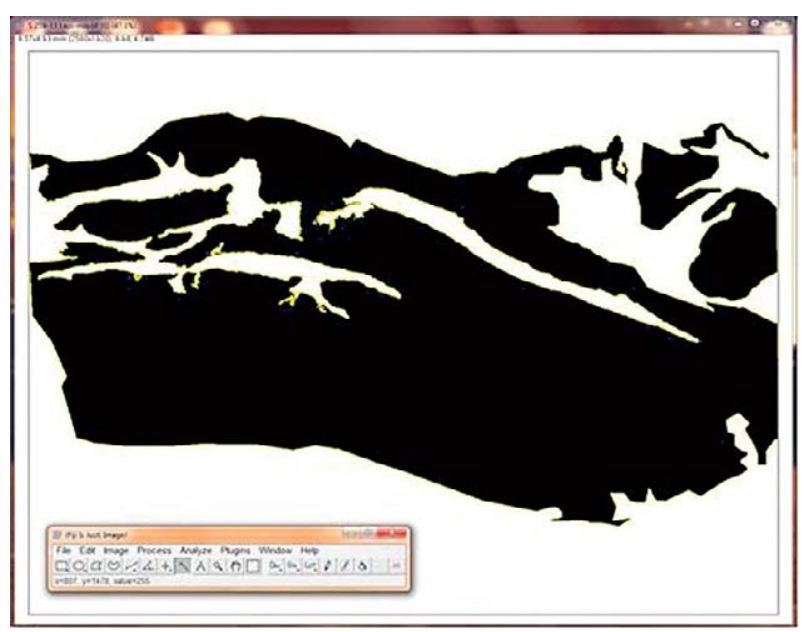

Fig. 3. Image shown in Figure 1 open in FIJI. The image was converted to 8-bit type image and thresholding was enabled for the wand tool, which was used to select the mask area, corresponding to the area of myocardial layer on the original image (yellow lining around the black mask denotes selection).

sue deposits were measured with the help of a thresholding-enabled wand tool (Fig. 3). This method was modified from the one used by Egan et al. for bone histomorphometry ${ }^{10}$. The shares of total myocardial fat (total myocardial fat area/myocardial layer area), perivascular fat (perivascular myocardial fat area/myocardial layer area) and non-perivascular fat (non-perivascular myocardial fat area/myocardial layer area) were calculated.

The mean epicardial thickness and fat to myocardium area ratios were statistically evaluated for differences between younger and older subjects, as well as with regard to sampling localization. The calculated values were analyzed using Statistica software ver. 13 (Dell Inc., Round Rock, USA). Mann-Whitney U test was used for testing differences between groups. All results were expressed as median and interquartile range; $p$ values were two-tailed with difference considered significant at $\mathrm{p}<0.05$.

\section{Results}

Overall 30 samples were obtained and one atrial sample was excluded from analysis due to inappropriate sampling. Therefore, 9 samples from the lateral wall of RA, 10 from the lateral free wall of RV and 10 from the $\mathrm{RV}$ apex were analyzed.

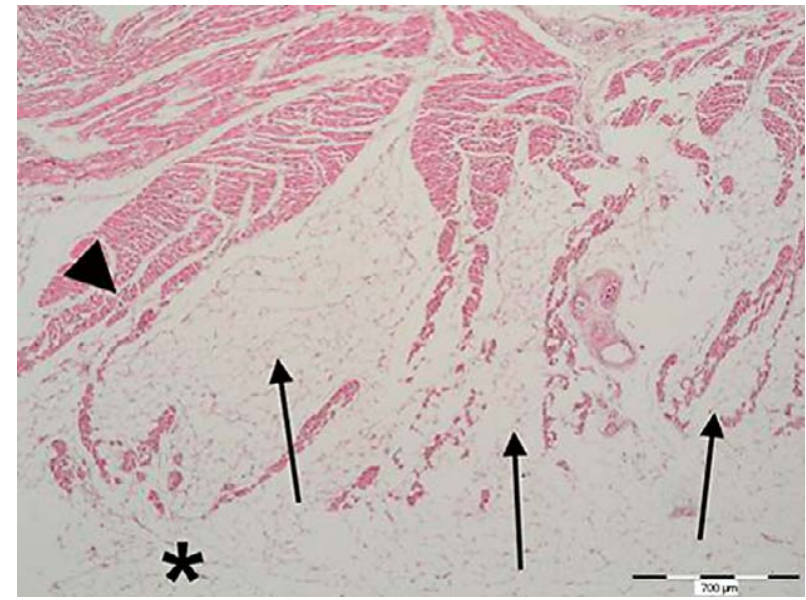

Fig. 4. A representative section of a sample taken from the $R V$ apex of a 68-year-old subject. Areas of fat tissue (arrows) protruding from the epicardium (asterisk) into the myocardium (arrow head). Fat tissue takes up a significant area in this particular region of myocardial layer. Scale bar: $700 \mu \mathrm{m}$.

Histologic sections revealed all three cardiac layers (epicardium, myocardium and endocardium). Fat deposits of different thickness were visible in the epicardium, and areas of fat tissue spanned into the myocardium in all samples, in both groups of subjects. These areas were partly perivascular fat that followed and encapsulated blood vessels entering the myocardium. Apart from that, fat deposits of various sizes not related to blood vessels were present in the myocardium of both RA and RV (Fig. 4).

Measurements showed that epicardial thickness was greater in older subjects and in ventricular samples; however, these differences were not statistically significant (Tables 1 and 2).

With regard to age, although the older group had somewhat larger amounts of fat in myocardium, there was no statistical difference between the groups (share of total myocardial fat $\mathrm{p}=0.847$, share of perivascular fat $\mathrm{p}=0.4$, and share of non-perivascular fat $\mathrm{p}=0.4$ ) (Table 1). There were no significant differences between the share of perivascular myocardial fat of RA and $\mathrm{RV}(\mathrm{p}=0.167)$ and the share of non-perivascular myocardial fat of RA and RV either $(\mathrm{p}=0.069)$ (Table 2). With regard to age, although the older group had larger amounts of fat both in epicardium and myocardium, no statistical difference was found between the groups (Table 1). 
Table 1. Analysis of the measured values according to age

\begin{tabular}{|l|l|l|l|l|}
\hline & $\begin{array}{l}\text { Average epicardium } \\
\text { thickness }(\mu \mathrm{m})\end{array}$ & $\begin{array}{l}\text { Share of total } \\
\text { myocardial fat }\end{array}$ & $\begin{array}{l}\text { Share of perivascular } \\
\text { myocardial fat }\end{array}$ & $\begin{array}{l}\text { Share of non-perivascular } \\
\text { myocardial fat }\end{array}$ \\
\hline Age group (yrs) & $\begin{array}{l}\text { Median } \\
\text { (interquartile range) }\end{array}$ & $\begin{array}{l}\text { Median } \\
\text { (interquartile range) }\end{array}$ & $\begin{array}{l}\text { Median } \\
\text { (interquartile range) }\end{array}$ & $\begin{array}{l}\text { Median } \\
\text { (interquartile range) }\end{array}$ \\
\hline$<50$ & $520.5(243.3-1001.9)$ & $0.062(0.018-0.21)$ & $0.025(0.008-0.049)$ & $0.034(0.005-0.112)$ \\
$>50$ & $656.1(407.4-1076.7)$ & $0.083(0.046-0.17)$ & $0.052(0.005-0.068)$ & $0.014(0.008-0.041)$ \\
p value* & 0.747 & 0.847 & 0.4 & 0.4 \\
\hline
\end{tabular}

*Mann-Whitney U test

Table 2. Analysis of the measured values according to sample localization

\begin{tabular}{|c|c|c|c|c|}
\hline & $\begin{array}{l}\text { Average epicardium } \\
\text { thickness }(\mu \mathrm{m})\end{array}$ & $\begin{array}{l}\text { Share of total } \\
\text { myocardial fat }\end{array}$ & $\begin{array}{l}\text { Share of perivascular } \\
\text { myocardial fat }\end{array}$ & $\begin{array}{l}\text { Share of non-perivascular } \\
\text { myocardial fat }\end{array}$ \\
\hline Location & $\begin{array}{l}\text { Median } \\
\text { (interquartile range) }\end{array}$ & $\begin{array}{l}\text { Median } \\
\text { (interquartile range) }\end{array}$ & $\begin{array}{l}\text { Median } \\
\text { (interquartile range) }\end{array}$ & $\begin{array}{l}\text { Median } \\
\text { (interquartile range) }\end{array}$ \\
\hline Atrium & $198.7(141.9-1206.0)$ & $0.046(0.014-0.108)$ & $0.015(0.004-0.046)$ & $0.008(0.003-0.041)$ \\
\hline Ventricle & $662.1(513.1-980.2)$ & $0.09(0.051-0.215)$ & $0.048(0.010-0.068)$ & $0.03(0.011-0.143)$ \\
\hline p value* & 0.140 & 0.044 & 0.167 & 0.069 \\
\hline
\end{tabular}

*Mann-Whitney U test

Table 3. Comparison of total myocardial fat area share among localizations

\begin{tabular}{|l|l|l|l|l|}
\hline Location & $\begin{array}{l}\text { Share of total myocardial fat, median } \\
\text { (interquartile range) }\end{array}$ & $\begin{array}{l}\text { p value* } \\
\text { (A vs. V) }\end{array}$ & $\begin{array}{l}\text { p value* } \\
\text { (V vs. VA })\end{array}$ & $\begin{array}{l}\text { p value* } \\
\text { (A vs. VA })\end{array}$ \\
\hline $\begin{array}{l}\text { Atrial free wall (A) } \\
\text { Ventricular free wall (V) } \\
\text { Ventricular apex (VA) }\end{array}$ & $\begin{array}{l}0.046(0.014-0.108) \\
0.075(0.0506-0.209)\end{array}$ & $0.15(0.0583-0.2204)$ & 0.684 & 0.044 \\
\hline
\end{tabular}

*Mann-Whitney U test

According to sample localization, RV samples had a significantly larger quantity of total fat deposited inside myocardium (Table 2). Since this fat was not evenly distributed between perivascular and non-perivascular areas, these particular subgroups did not differ significantly between locations. Looking at median values of total fat area share, the largest quantities of fat tissue inside myocardial layer were found in the samples from the RV apex (14.99\%), followed by RV free wall values $(7.5 \%)$ and then RA free wall values (4.56\%). Hence, further analysis showed that total myocardial fat share from the RV apex sample was significantly larger than that of RA sample $(\mathrm{p}=0.044)$, but no statistical difference existed between RA and RV free lateral wall ( $\mathrm{p}=0.156)$ or between two RV samples $(p=0.684)$. Nevertheless, a clear tendency of increase in total fat tissue area within the myocardium from the atrium towards the apex is shown in Table 3.

\section{Discussion}

Histologic assessment performed in this study confirmed and characterized the presence of intramyocardial fat tissue in the RA and RV of subjects without apparent heart disease. While there was no statistically significant difference in the occurrence of intramyocardial fat tissue between younger and older subjects, there was a tendency towards a somewhat larger amount of fat observed in the group of older subjects. Additionally, we found an increase in total fat tissue area within the myocardium from the atrium towards the apex, with a significantly larger quantity of 
total intramyocardial fat deposited in the RV compared to the RA. Increased fat tissue deposit in the apical RV part can present a locus minoris for morphological and hemodynamic changes ${ }^{11}$.

There is no consensus yet about the exact physiological and pathophysiological significance of intramyocardial fat tissue. Although fibrofatty replacement of the right ventricle wall, which is often associated with inflammation, is a main characteristic of arrhythmogenic right ventricular cardiomyopathy and associated with sudden cardiac death, research conducted in the past years points to the possible occurrence of fat infiltration without fibrosis also in the normal heart ${ }^{12}$. Tansey et al. found variable amounts of intramyocardial fat (with up to $85 \%$ of hearts containing at least some intramyocardial fat) in subjects dying of noncardiac related causes. This simple fatty infiltration was not associated with arrhythmogenic right ventricular cardiomyopathy ${ }^{12}$. It is therefore open to discussion how to interpret the role of this intramyocardial fat tissue in health and/or disease; among other questions, does it exert any paracrine/endocrine effects, contribute to normal development of the heart and to physiological changes and adaptation during aging, have any contributive effect on pathophysiological processes in disease states, increase the risks of adverse outcomes, etc. Another issue is if and how is this intramyocardial adipose tissue functionally related to fat inside cardiomyocytes (triglyceride droplets) and myocardial steatosis. Interestingly, epicardial adipose tissue has garnered wide interest in studies over years and data have been collected to point to its extensive metabolic and endocrine functions although it has once been considered only as a storage compartment ${ }^{13}$. It actually serves as an endocrine and paracrine organ, contributing to the homeostasis of body energy, lipid and carbohydrate metabolism, having vasocrine regulative functions in the heart, being a major source of anti-inflammatory and proinflammatory adipokines, and considered a potential risk factor for cardiovascular diseases such as coronary syndromes ${ }^{13}$. On the other hand, such potential key roles of intramyocardial fat tissue are less clear and studies are fewer in numbers.

Advances in imaging studies have made it possible to detect intramyocardial fat with a high degree of confidence. Noninvasive approaches including computed tomography (CT) and magnetic resonance imaging enable observation of fibrofatty infiltration of the myocardium in healthy subjects and in conditions of cardiomyoptahy, states after myocardial infarction, arrhythmogenic right ventricular dysplasia, and others $^{5,14-17}$. Fat and water-separated imaging techniques are sensitive for detection of intramyocardial fat and they also may be combined with late-enhancement imaging to provide positive correlation between fibrosis and fat. Such methods have the potential for quantitative measurement of fat in the heart and could be used for assessment of its prognostic value in various conditions ${ }^{5}$. An interesting study by Matsuo et al. correlated CT features of myocardial fat with clinical background in patients without cardiac disease. They observed myocardial fat in $68.5 \%$ of patients, most commonly in the RV outflow tract (64.1\%), followed by the base (42.3\%) and middle (28.9\%) of the RV free wall, RV trabeculations (22.5\%), and the left ventricular apex $(11.4 \%)^{18}$. In addition to being most often observed in the RV outflow tract, it was more frequent in female patients, those older than 65 years, those with body mass index $\geq 25$, and those with hypertension ${ }^{18}$. These results are somewhat different from the histologic results presented in this study where the intramyocardial fat was most pronounced in samples from the RV apex, but the methodology, of course, was not equivalent.

There have been some histopathologic studies seeking to explore fatty infiltration of the heart. Examples of studies determining fatty infiltration in ventricular scarring include the work by Baroldi et al., who conducted a retrospective analysis of left ventricular scars on autopsies ${ }^{19}$. Lipomatous metaplasia of myocardial scar was observed in $68 \%$ of ischemic heart disease, $37 \%$ of chronic valvulopathy, $26 \%$ of idiopathic dilated cardiomyopathy, $15 \%$ of chagasic patients, and $55 \%$ of aneurysm walls. Based on available data, the authors conclude that lipomatous metaplasia of scars is often associated with severe heart failure, is more frequent and extensive in ischemic heart disease, and that transformation of a compact scar into compressible adipose tissue worsens ventricular wall function, thus facilitating and/or aggravating aneurysm formation ${ }^{19}$. $\mathrm{Su}$ et al. reviewed medical records on 91 hearts from patients undergoing heart transplantation for ischemic heart disease to determine the extent of adipose tissue within healed myocardial infarction. Of the 91 hearts examined, 168 healed myocardial infarctions were identified with 141 (84\%) containing some mature fat. Adipose tissue increased with age, in males, and in 
those patients who had undergone coronary bypass graft surgery. The amount of adipose tissue was not related to the location or age of the healed myocardial infarction ${ }^{20}$. This is an interesting finding compared with our results on subjects without heart disease, where we found a significant difference in intramyocardial adipose tissue according to location, but no clear and significant difference between age groups, at least as defined by our study design. This contrasts the apparent nature of the adipose tissue that forms in scars compared to the 'physiologically' present adipose tissue within the myocardium. Caruso et al. conducted a histologic comparative study between endomyocardial biopsies obtained from 138 patients with various cardiac pathologies and 42 autopsy heart samples, measuring the amount of adipose tissue in isolation or associated with fibrous tissue. Fibro-adipose tissue was found in 7 of 42 hearts from autopsy (which did not have right ventricular dysplasia), with different distribution in the two ventricles, but to a maximum amount of $20 \%$ of the section. The right side of the ventricular septum was affected in five cases ${ }^{6}$. They observed a quantitative difference between this fibro-adipose tissue in normal hearts and the fibro-adipose tissue found in right ventricular endomyocardial biopsies in cases with right ventricular dysplasia, where the fibro-adipose tissue presence was more prevalent ${ }^{6}$. This is also a surprising difference compared with our data, as we found intramyocardial adipose tissue in all sampled subjects with normal hearts, whereas the older study by Caruso et al. found it in 7 of 42 normal heart samples from autopsy ( 5 cases on the right side of the ventricular septum $)^{6}$.

Since the exact functional implications of intramyocardial fat tissue remain to be elucidated, an important prerequisite and foundation for further functional analyses is good characterization of morphology, quantity and location of this tissue in the myocardium in both healthy and diseased states. Such morphological information, when taken together with other information such as age and clinical characteristics of the subjects, can provide key hints to its function and clinical implications. In this regard, the presented results are helpful in broadening our insights into the presence and distribution of myocardial fat tissue in the right atrium and ventricle, thereby providing reference for further research. The precise and well defined computerized histologic quantification methods enable comparisons with data of similar studies in the future.
The limitations of our study included a relatively small sample size, although it is noteworthy that it was performed with valuable human heart samples of subjects with no evident heart disease on autopsy and no other specific autopsy findings, which are relatively rare. A more detailed age stratification, which would be possible with larger subject sample groups, could provide more information on changes during aging. Furthermore, inclusion of female subjects could contribute to assessment of gender and hormonal influences on intramyocardial fat tissue in subsequent studies.

\section{Conclusion}

Currently available data in the discussed subject area are very limited, especially those obtained from histopathologic analyses in humans. The findings of intramoycardial/epicardial fat tissue are interesting as observed from several points of view, i.e. the origin and embryogenic development within the right heart, the physiologic role of triglyceride droplets in cardiomyocyte metabolism, the impact of epicardial adipose tissue on the myocardium with possible paracrine/autocrine effects on coronary microcirculation and cardiomyocytes, changes in RA and RV morphology with consequential effects on intracardiac pressure and hemodynamics, changes in the structure of the conduction system, which could serve as pro-arrhythmogenic substrates, the aging process as part of physiology, and gender differences.

According to our results, we conclude that intramyocardial fat and epicardial fat tissue are present in all samples, predominantly in $\mathrm{RV}$ apex without age difference with this sample size. Further investigation in this area is needed to elucidate RA and RV fat tissue physiology and pathophysiology.

\section{References}

1. Samanta R, Pouliopoulos J, Thiagalingam A, Kovoor P. Role of adipose tissue in the pathogenesis of cardiac arrhythmias. Heart Rhythm. 2016;13(1):311-20.

doi: 10.1016/j.hrthm.2015.08.016.

2. Iozzo P. Myocardial, perivascular, and epicardial fat. Diabetes Care. 2011;34 Suppl 2:S371-9. doi: 10.2337/dc11-s250.

3. Mordi I, Radjenovic A, Stanton T, Gardner RS, McPhaden A, Carrick D, et al. Prevalence and prognostic significance of lipomatous metaplasia in patients with prior myocardial infarction. JACC Cardiovasc Imaging. 2015;8(9):1111-2. doi: 10.1016/j.jcmg.2014.07.024. 
4. Pouliopoulos J, Chik WW, Kanthan A, Sivagangabalan G, Barry MA, Fahmy PN, et al. Intramyocardial adiposity after myocardial infarction: new implications of a substrate for ventricular tachycardia. Circulation. 2013;128(21):2296-308. doi: 10.1161/CIRCULATIONAHA.113.002238.

5. Kellman P, Hernando D, Arai AE. Myocardial fat imaging. Curr Cardiovasc Imaging Rep. 2010;3(2):83-91.

6. Caruso G, Frassanito F, Serio G, Pennella A. Is adipose tissue a normal component of the myocardium? Eur Heart J. 1989; 10 Suppl D:89-91.

7. Selthofer-Relatić K, Bošnjak I. Myocardial fat as a part of cardiac visceral adipose tissue: physiological and pathophysiological view. J Endocrinol Invest. 2015;38(9):933-9. doi: 10.1007/s40618-015-0258-y.

8. Schindelin J, Arganda-Carreras I, Frise E, Kaynig V, Longair M, Pietzsch T, et al. Fiji: an open-source platform for biological-image analysis. Nat Methods. 2012;9(7):676-82. doi: 10.1038/nmeth.2019.

9. Schindelin J, Rueden CT, Hiner MC, Eliceiri KW. The ImageJ ecosystem: an open platform for biomedical image analysis. Mol Reprod Dev. 2015;82(7-8):518-29.

doi: $10.1002 / \mathrm{mrd} .22489$.

10. Egan KP, Brennan TA, Pignolo RJ. Bone histomorphometry using free and commonly available software. Histopathology. 2012;61(6):1168-73. doi: 10.1111/j.1365-2559.2012.04333.x.

11. Selthofer-Relatić K. Cardiac visceral adiposity and right ventricle apex remodeling - locus minoris resistentiae. Med Hypotheses. 2014;82(3):401. doi: 10.1016/j.mehy.2013.12.001.

12. Tansey DK, Aly Z, Sheppard MN. Fat in the right ventricle of the normal heart. Histopathology, 2005;46(1):98-104.

13. Salazar J, Luzardo E, Mejías JC, Rojas J, Ferreira A, Rivas-Ríos $\mathrm{JR}$, et al. Epicardial fat: physiological, pathological, and thera- peutic implications. Cardiol Res Pract. 2016;2016:1291537. doi: 10.1155/2016/1291537.

14. Kellman P, Bandettini WP, Mancini C, Hammer-Hansen S, Hansen MS, Arai AE. Characterization of myocardial T1mapping bias caused by intramyocardial fat in inversion recovery and saturation recovery techniques. J Cardiovasc Magn Reson. 2015;17:33. doi: 10.1186/s12968-015-0136-y.

15. Sasaki T, Calkins H, Miller CF, Zviman MM, Zipunnikov V, Arai $\mathrm{T}$, et al. New insight into scar-related ventricular tachycardia circuits in ischemic cardiomyopathy: fat deposition after myocardial infarction on computed tomography - a pilot study. Heart Rhythm. 2015;12(7):1508-18. doi: 10.1016/j.hrthm.2015.03.041.

16. Saremi F, Saremi A, Hassani C, Cen S, Lin L, Ng B, Shahriarian S. Computed tomographic diagnosis of myocardial fat deposits in sarcoidosis. J Comput Assist Tomogr. 2015;39(4): 578-83. doi: 10.1097/RCT.0000000000000235.

17. Kirsch J, Williamson EE, Glockner JF. Focal macroscopic fat deposition within the right ventricular wall in asymptomatic patients undergoing screening EBCT coronary calcium scoring examinations. Int J Cardiovasc Imaging. 2008;24(2):223-7.

18. Matsuo Y, Kimura F, Nakajima T, Inoue K, Mizukoshi W, Kozawa $\mathrm{E}$, et al. CT features of myocardial fat and correlation with clinical background in patients without cardiac disease. Jpn J Radiol. 2013;31(7):444-54. doi: 10.1007/s11604-013-0212-x.

19. Baroldi G, Silver MD, Maria R, Parodi O, Pellegrini A. Lipomatous metaplasia in left ventricular scar. Can J Cardiol. 1997;13:65-71.

20. Su L, Siegel JE, Fishbein MC. Adipose tissue in myocardial infarction. Cardiovasc Pathol. 2004;13:98-102.

Sažetak

\section{POJAVNOST INTRAMIOKARDIJALNIH MASNIH STANICA U STIJENCI DESNE PRETKLIJETKE I DESNE KLIJETKE - POSTMORTALNA HUMANA ANALIZA}

\section{K. Selthofer-Relatic, T. Belovari, N. Bijelic, A. Kibel i J. Rajc}

Dosadašnja histološka i radiološka istraživanja opisuju pojavnost intramiokardijalnog masnog tkiva kao dio normalnog nalaza ili kao dio patološkog nalaza srca. Uloga intramiokardijalnih masnih stanica nije još razjašnjena. Cilj ovoga istraživanja bio je utvrditi raspodjelu masnog tkiva u miokardu desne pretklijetke (DP) i desne klijetke (DK) ovisno o dobi i lokalizaciji kod ispitanika bez kardijalnog morbiditeta. Patohistološka postmortalna studija uključila je 10 muškaraca bez kardijalnih bolesti podijeljenih u dvije skupine prema dobi (ispod/iznad 50 godina). Uzorci su uzeti u tri presjeka (projekcija slobodnog zida DK, slobodni zid vrha DK te stijenka DP) s histomorfološkom analizom na digitalnim fotografijama. Izračunati su udjeli ukupnog masnog tkiva unutar srčanog mišića (UMT), perivaskularnog masnog tkiva (PMT) i ne-perivaskularnog masnog tkiva (nPMT). U uzorcima starijih ispitanika prisutna je veća količina masnog tkiva u epikardu i miokardu, bez statistički značajne razlike (UMT p=0,847, PMT p=0,4, nPMT p=0,4). Najveće količine masnog tkiva pronađene su u uzorcima vrha DK (14,9\%), nakon čega slijedi stijenka slobodnog zida DK (7,5\%) i DP (4,5\%), gdje je ukupni udio masnog tkiva DK bio znatno veći nego kod uzorka DP $(\mathrm{p}=0,044)$. Intramiokardijalne masne stanice sastavni su dio histološkog nalaza DP i DK u svim uzorcima bez prisutnih kardijalnih bolesti, dominantno u vrhu DK. Neophodna su daljnja istraživanja utjecaja dobi, spola i visceralne pretilosti na pojavnost intramiokardijalnih masnih stanica unutar stijenke desnog srca.

Ključne riječi: Miokard - patologija; Perikard - patologija; Srčane pretklijetke; Srčane klijetke; Srčane bolesti; Adipozno tkivo - patologija; Masno tkivo, distribucija - epidemiologija 